\title{
Expression of genes and their responses to enzyme replacement therapy in a Fabry disease mouse model
}

\author{
EUN-SOOK PARK* ${ }^{*}$ JIN-OK CHOI*, JOO-WON PARK, MI HEE LEE, HAE-YOUNG PARK and SUNG-CHUL JUNG
}

Department of Biochemistry, School of Medicine, Ewha Womans University, Seoul 158-710, Korea

Received March 13, 2009; Accepted June 3, 2009

DOI: 10.3892/ijmm_00000246

\begin{abstract}
Fabry disease is a lysosomal storage disease caused by a deficiency of $\alpha$-galactosidase $\mathrm{A}$, which results in aberrant glycosphingolipid metabolism and accumulation of globotriaosylceramide (Gb3). Since a correlation between the level of Gb3 and clinical manifestations of Fabry disease has not been observed, we investigated potential diagnostic biomarkers. Hepatic and renal gene expression of male $\alpha$-galactosidase Adeficient mice (Fabry mice) was compared with that of wildtype mice. Microarray analyses were performed using samples taken before and after intravenous infusion of $\alpha$-galactosidase A. The identified genes were validated using quantitative realtime PCR and Western blot assay. Expression of hepatic Serum Amyloid A1 (Saal), S100 Calcium-binding protein A8 and A9 (S100a8 and $a 9$ ), and Lipocalin 2 (Lcn2) and renal Neuropeptide Y (Npy), Thrombospondin 2 and 4 (Tsp-2 and -4) was significantly upregulated in Fabry mice compared with wild-type mice and normalized by enzyme replacement therapy. Plasma concentrations of Lcn2 and Npy were also greater in Fabry mice and reduced to wild-type levels after enzyme replacement therapy, although the plasma concentrations of these proteins show heterogeneity. Upregulation of Saal, S100a8, S100a9 and Lcn2 may modulate inflammation and Lcn2, Npy and Tsp may be associated with vascular and renal involvement in Fabry disease. Furthermore, these genes are promising targets for developing biomarkers for monitoring disease progression and therapeutic efficacy in patients with Fabry disease.
\end{abstract}

Correspondence to: Dr Sung-Chul Jung, Department of Biochemistry, School of Medicine, Ewha Womans University, 911-1 Mok-Dong, Yangcheon-Gu, Seoul 158-710, South Korea

E-mail: jungsc@ewha.ac.kr

*Contributed equally

Key words: Fabry disease, $\alpha$-galactosidase A, mouse, microarray, gene expression, biomarker, Lipocalin2, Neuropeptide Y

\section{Introduction}

Fabry disease is an X-linked lysosomal storage disorder caused by a deficiency of $\alpha$-galactosidase A ( $\alpha$-Gal A; EC 3.2.1.22) (1). This causes accumulation of glycosphingolipids, particularly globotriaosylceramide (Gb3), also known as ceramide trihexoside, in most cell types (2). Glycolipid accumulates predominantly in the endothelial cells of the kidney, heart, liver and spleen and in the plasma. With increasing age, progressive accumulation of glycolipid in vital organs causes renal, cardiac and cerebrovascular complications (3). However, the pathologic mechanism by which endothelial dysfunction occurs is unclear.

The most efficient and reliable method of diagnosing Fabry disease is to determine the activity of $\alpha$-Gal A in plasma, isolated leukocytes, or cultured cells. $\alpha$-Gal A enzyme replacement therapy (ERT) has been available since 2001 . The safety and efficacy of ERT were demonstrated in preclinical trials $(4,5)$. Although $\alpha$-Gal A ERT clears Gb3 from endothelial cells, its clinical effects are not as pronounced as predicted (6). ERT stabilizes renal function and attenuates cardiac hypertrophy in some patients, but others experience progressive complication (7). These findings suggest that an elevated level of Gb3 is not necessarily correlated with the clinical manifestation of Fabry disease. Therefore, there is a need to elucidate the etiology of this disease and to identify biomarkers for diagnosis, monitoring disease progression and testing the effect of therapies in clinical trials.

We examined gene expression in Fabry mice using a microarray technique to identify genes associated with the pathogenesis of Fabry disease and potential biomarkers. We subsequently evaluated whether ERT reduces overexpression of genes in Fabry disease.

\section{Materials and methods}

Animals. A pair of Fabry mice, provided by Dr Roscoe O. Brady of the National Institutes of Health (Bethesda, MD, USA), was bred to acquire a sufficient number of mice for this study. The mice were 15 weeks old at the inception of the study. All mice were genotyped using PCR as described previously (8). A minimum of three age-matched animals were used for each group. Mice were fed an autoclaved diet and water ad libitum. All animals were treated in accordance with the Animal Care 
Guidelines of the Ewha Woman's University School of Medicine (Seoul, Korea) and the National Institutes of Health Guide for the Care and Use of Laboratory Animals. For ERT, Fabry mice received an infusion of $1 \mathrm{mg} / \mathrm{kg}$ body weight of $\alpha$-Gal A (Genzyme, Cambridge, MA, USA) in normal saline via the tail vein.

$\alpha$-Gal A assay. A fluorimetric assay for $\alpha$-Gal A was performed as previously described (9) with minor modifications. Tissue samples were homogenized and sonicated in an aqueous buffer containing $5 \mathrm{mg} / \mathrm{ml}$ sodium taurocholate, $\mathrm{pH} 4.4$ and then centrifuged at $20,000 \times \mathrm{g}$ for $30 \mathrm{~min}$. $\alpha$-Gal A activity was determined by incubating aliquots of supernatant at $37^{\circ} \mathrm{C}$ in a $\mathrm{pH} 4.4$ buffer containing $28 \mathrm{mM}$ citric acid, $44 \mathrm{mM}$ disodium phosphate, $5 \mathrm{mM}$ 4-methylumbelliferyl- $\alpha$-D-galactopyranoside, $4 \mathrm{mg} / \mathrm{ml}$ bovine serum albumin and $0.1 \mathrm{M} \mathrm{N}$-acetylgalactosamine, a specific inhibitor of $\mathrm{N}$-acetylgalactosaminidase.

Quantitation of Gb3 levels. Extraction and saponification of lipids and extraction of the glycolytic fraction were performed as described previously (10). The glycolipid fraction was mixed with $5 \mu 1$ of ISTD ( $\mathrm{N}$-acetyl-galactosylsphingosine) and $795 \mu 1$ of $80 \%$ dioxane and then analyzed using a liquid chromatography-mass/mass spectrometer (LC-MS/MS, ABI 4000, Applied Biosystems, Foster City, CA, USA). Quantitation of glycolipids was done using a C8 column and an evaporative light-scattering detector. The Gb3 standard was obtained from Matreya (Pleasant Gap, PA, USA).

Oligonucleotide microarray analysis. The livers and kidneys of wild-type mice, untreated and ERT Fabry mice (four mice from each group) were pooled to minimize interanimal variability, and total RNA was extracted using a Ribopure Kit (Ambion, Austin, TX, USA) according to the manufacturer's protocol. The integrity of RNA was examined by electrophoresis using a 2100 Bioanalyzer (Agilent Technologies, Palo Alto, CA, USA). Total RNA ( $3 \mu \mathrm{g})$ from each group was amplified separately and labeled with either Cy3 or Cy5 using an Agilent Low RNA Input Fluorescent Linear Amplification Kit (Agilent Technologies). Cy3- and Cy5-labeled targets were hybridized to an Agilent 44K mouse oligo array at $60^{\circ} \mathrm{C}$ for $17 \mathrm{~h}$. After hybridization, arrays were washed in three consecutive steps with the following buffers, $6 \times$ SSPE containing $0.005 \% \mathrm{~N}$-lauroylsarcosine, $0.06 \mathrm{x}$ SSPE containing $0.005 \% \mathrm{~N}$-lauroylsarcosine and Agilent stabilization solution. Microarrays were scanned using ScanArray 3.0 (Packard BioScience, Billerica, MA, USA) and data were analyzed using GenePix Pro 4.0 (Axon Instruments, Burlingame, CA, USA).

$R T$-PCR and real-time PCR. Total RNA was extracted from livers and kidneys using a Ribopure Kit (Ambion) according to the manufacturer's instructions. Total RNA $(2 \mu \mathrm{g})$ was reverse transcribed using oligo-(dT) $)_{15}$ primers and a Power cDNA Synthesis Kit (Intron Biotechnology, Seongnam, Korea). RT product was amplified by PCR, which was performed in a volume of $20 \mu \mathrm{l}$ containing $2 \mu \mathrm{l}$ RT products as template, $1 \mathrm{X}$ reaction buffer, $20 \mathrm{pmol}$ of each primer and $0.5 \mathrm{U}$ of Taq DNA polymerase (Intron Biotechnology). PCR amplification conditions were $94^{\circ} \mathrm{C}$ for 5 min followed by 25 cycles at $94^{\circ} \mathrm{C}$ for $30 \mathrm{sec}, 60^{\circ} \mathrm{C}$ for $30 \mathrm{sec}$ and $72^{\circ} \mathrm{C}$ for $30 \mathrm{sec}$ with an extension time of $72^{\circ} \mathrm{C}$ for $7 \mathrm{~min}$. The RT-PCR products were analyzed using 1.5\% agarose gel electrophoresis. Primer sets were designed using Primer3 (http://frodo.wi.mit.edu/) and estimated product sizes were $\sim 100 \mathrm{bp}$. Real-time PCR was performed using the SYGR Green System (Applied Biosystems) to confirm the relative expression of genes among the three groups. Hypoxanthine guanine phosphoribosyl transferase (Hprt) was used as an endogenous murine control gene (11). Amplification was performed using $0.2 \mu \mathrm{g}$ of cDNA products in a total reaction volume of $20 \mu 1$ and an ABI PRISM 7000 Sequence detection system (Applied Biosystems). Amplification condition was 40 cycles at $95^{\circ} \mathrm{C}$ for $60 \mathrm{sec}$ and $60^{\circ} \mathrm{C}$ for $60 \mathrm{sec}$. The accuracy of gene amplification was validated using a dissociation curve. The relative expression of genes among groups was calculated using the $2^{-\Delta \Delta \mathrm{C} t}$ method (12).

Western blotting. Tissue (10-20 mg) from samples that were stored in liquid nitrogen was homogenized in Pro-Prep solution (Intron Biotechology). The tissue lysate was centrifuged at $13,000 \mathrm{x} \mathrm{g}$ for $30 \mathrm{~min}$, and the supernatant was collected and heated at $100^{\circ} \mathrm{C}$ for $3 \mathrm{~min}$. Equal amounts of protein were separated by $8-13 \%$ SDS-PAGE and transferred to polyvinylidene difluoride membrane (Millipore, Bedford, MA, USA). The membranes were blocked using 5\% skim milk in TBST (20 mM Tris-HCl, pH 7.5; $500 \mathrm{mM} \mathrm{NaCl}$; and $0.1 \%$ Tween-20) for $2 \mathrm{~h}$ at room temperature and were then sequentially incubated with primary antibodies, polyclonal anti-mouse Lipocalin2 (Lcn2) antibody, polyclonal anti-mouse Serum Amyloid A1 antibody, polyclonal anti-mouse S100a8 antibody, polyclonal anti-mouse S100a9 antibody (all from R\&D Systems, Minneapolis, MN, USA), mouse monoclonal anti-thromobospondin-1 (Tsp-1) antibody (Thermo Fisher Scientific, Waltham, MA, USA), anti-mouse Tsp-2 antibody (BD Biosciences, San Jose, CA, USA), anti-mouse Tsp-4 antibody (Santa Cruz Biotechnology, San Diego, CA, USA), or B-actin antibody (Sigma-Aldrich, St Louis, MO, USA). Membranes were then washed and incubated with the HRPconjugated secondary antibodies, anti-rabbit, -goat and -mouse IgG (Santa Cruz Biotechnology). The washes were repeated and membranes were developed using a chemiluminescent agent (ECL; GE Healthcare, Buckinghamshire, UK) and visualized using a Bio-Imaging analyzer (LAS-3000, Fuji, Tokyo, Japan). The relative protein expression level of an individual gene for each sample was normalized against $\beta$-actin or GAPDH expression.

Plasma Lcn2 concentration. Plasma Lcn2 concentration was estimated using the Duoset ELISA development system (R\&D Systems). Briefly, 96-well, flat-bottom microtiter plates were coated with diluted capture antibody and blocked. Subsequently, standard and plasma were diluted in blocking reagent and incubated. After washing, the detection antibody (biotinylated rat anti-mouse Lcn2) was added and incubated. Streptavidin-HRP and substrate solution were added and incubated. The OD $450 \mathrm{~nm}$ was determined using a Versamax microplate reader (Molecular Devices, Menlo Park, CA, USA). Plasma Lcn 2 concentrations in Fabry mice were determined after three weekly injections of $\alpha$-galactosidase A. 
Table I. Gene expression patterns in the liver of Fabry mice before and after enzyme replacement therapy.

\begin{tabular}{|c|c|c|c|c|}
\hline \multirow[b]{2}{*}{ Gene symbol } & \multirow[b]{2}{*}{ Gene name } & \multirow[b]{2}{*}{ GenBank accession no. } & \multicolumn{2}{|c|}{ Ratio of expression (fold) } \\
\hline & & & $\mathrm{U} / \mathrm{W}^{\mathrm{a}}$ & $\mathrm{T} / \mathrm{U}^{\mathrm{b}}$ \\
\hline \multicolumn{5}{|l|}{ Upregulated } \\
\hline Cxcll & Chemokine (C-X-C motif) ligand 1 & NM_008176 & 7.09 & 0.455 \\
\hline Chi3ll & Chitinase 3 -like 3 & NM_009892 & 2.321 & 0.674 \\
\hline Gpr173 & G-protein coupled receptor 173 & NM_027543 & 2.03 & 0.898 \\
\hline S100a4 & S100 calcium binding protein A4 & NM_011311 & 2.295 & 0.915 \\
\hline S100a8 & S100 calcium binding protein A8 (calgranulin A) & NM_013650 & 2.96 & 0.264 \\
\hline a9 & S100 calcium binding protein A9 (calgranulin B) & NM_009114 & 5.755 & 0.342 \\
\hline Saal & Serum amyloid A 1 & NM_009117 & 5.129 & 0.271 \\
\hline Saa2 & Serum amyloid A 2 & NM_011314 & 5.154 & 0.309 \\
\hline Saa3 & Serum amyloid A 3 & NM_011315 & 5.035 & 0.452 \\
\hline $\operatorname{Lcn} 2$ & Lipocalin 2 & NM_008491 & 2.762 & 0.367 \\
\hline$T s h r$ & Thyroid stimulating hormone receptor & NM_011648 & 2.033 & 0.839 \\
\hline \multicolumn{5}{|l|}{ Downregulated } \\
\hline Arsk & Arylsufatase K & NM_029847 & 0.131 & 1.604 \\
\hline Gdf10 & Growth differentiation factor 10 & NM_145741 & 0.274 & 1.356 \\
\hline Mme & Membrane metallo endopeptidase & NM_008604 & 0.393 & 1.093 \\
\hline Txnip & Thioredoxin interacting protein & NM_023719 & 0.436 & 2.242 \\
\hline
\end{tabular}

The ratio of expression is represented in fold, based on the microarray analysis. ${ }^{\mathrm{a}} \mathrm{U} / \mathrm{W}$, untreated Fabry mice/wild-type mice, ${ }^{\mathrm{b}} \mathrm{T} / \mathrm{U}$, enzymetreated Fabry mice/untreated Fabry mice.

Table II. Gene expression patterns in the kidney of Fabry mice before and after enzyme replacement therapy.

\begin{tabular}{|c|c|c|c|c|}
\hline \multirow[b]{2}{*}{ Gene symbol } & \multirow[b]{2}{*}{ Gene name } & \multirow[b]{2}{*}{ GenBank accession no. } & \multicolumn{2}{|c|}{ Ratio of expression (fold) } \\
\hline & & & $\mathrm{U} / \mathrm{W}^{\mathrm{a}}$ & $\mathrm{T} / \mathrm{U}^{\mathrm{b}}$ \\
\hline \multicolumn{5}{|l|}{ Upregulated } \\
\hline Npy & Neuropeptide Y & NM_023456 & 2.452 & 0.574 \\
\hline Ntsr 2 & Neurotensin receptor 2 & NM_008747 & 2.452 & 0.574 \\
\hline Rasa3 & RAS p 21 protein activator 3 & NM_009025 & 2.147 & 1.022 \\
\hline S100a4 & S100 calcium binding protein A4 & NM_011311 & 2.092 & 1.039 \\
\hline Tsp4 & Thrombospondin 4 & NM_011582 & 2.295 & 0.845 \\
\hline Tsp2 & Thrombospondin 2 & NM_011581 & 2.91 & 1.938 \\
\hline \multicolumn{5}{|l|}{ Downregulated } \\
\hline Arsk & Arylsufatase K & NM_029847 & 0.137 & 1.545 \\
\hline$C d 36$ & CD36 antigen & NM_007643 & 0.49 & 1.026 \\
\hline$H s d 11 b 1$ & Hydroxysteroid $11-\beta$ dehydrogenase 1 & NM_008288 & 0.383 & 1.118 \\
\hline Rnase4 & Ribonuclease, RNase A family 4 & NM_021472 & 0.267 & 3.041 \\
\hline Synpr & Synaptoporin & NM_028052 & 0.048 & 1.938 \\
\hline
\end{tabular}

The ratio of expression is represented in fold, based on the microarray analysis. ${ }^{\mathrm{a}} \mathrm{U} / \mathrm{W}$, untreated Fabry mice/wild-type mice, ${ }^{\mathrm{b}} \mathrm{T} / \mathrm{U}$, enzymetreated Fabry mice/untreated Fabry mice.

Plasma neuropeptide Y concentration. Plasma neuropeptide Y (Npy) concentration was estimated using an enzyme immunoassay kit from Phoenix Pharmaceuticals Inc. (Burlingame, CA, USA) after extraction of peptides from plasma with Sep-Column C18 Cartridges (Phoenix Pharmaceuticals Inc.).

Statistical analysis. The statistical significance of differences between groups was determined using Student's t test. Data are presented as the mean \pm standard deviation, \pm SD. Nullhypothesis probabilities $<0.05$ were considered significant.

\section{Results}

a-Gal A activity and Gb3 level after ERT. A significant increase in enzyme activity in the organs tested was detected one week after injection. $\alpha-$ Gal A activity was 94.21 +5.29 
$\mathbf{A}$

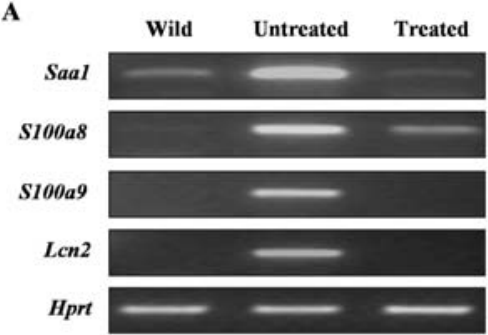

B

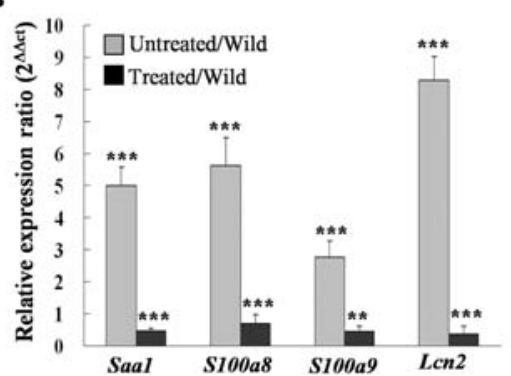

Figure 1. A, Semiquantitative RT-PCR analysis of Lcn2, S100a8, S100a9 and Saal expression in the mouse liver. Total RNA from livers of untreated, treated and wild-type mice was purified from three mice per group. B, Expression levels of genes in mouse liver analyzed by quantitative real-time PCR and expressed relative to those of wild-type mice. Data are presented as the means \pm SD of three experiments. ${ }^{*} \mathrm{p}<0.05,{ }^{* *} \mathrm{p}<0.01$ and ${ }^{* * *} \mathrm{p}<0.001$ for wildtype vs untreated Fabry mice or for untreated Fabry vs treated Fabry mice according to Student's t test.

and $55.58 \pm 7.85 \mathrm{nmol} / \mathrm{h} / \mathrm{mg}$ protein in the liver and kidney, respectively. These enzyme activities were very similar to those in wild-type mice $(75.66 \pm 8.75$ and $68.27 \pm 4.14 \mathrm{nmol} / \mathrm{h} / \mathrm{mg}$ protein in liver and kidney, respectively). Liver tissue Gb3 levels were also reduced to within the normal range by ERT. The kidney Gb3 level of untreated Fabry mice that received ERT $(0.821 \pm 0.0101 \mathrm{nmol} / \mathrm{mg}$ protein $)$ was less than that of age-matched untreated Fabry mice $(8.034 \pm 0.6511 \mathrm{nmol} / \mathrm{mg}$ protein). However, the Gb3 level of treated Fabry mice was greater than that of age-matched wild-type mice $(0.281 \pm 0.0665 \mathrm{nmol} / \mathrm{mg}$ protein $)$.

Gene expression profiles in liver and kidney tissue. We measured gene transcript alterations in a mouse model of Fabry disease one week after ERT. Table I shows up- or downregulated genes, but normalized after ERT in the liver Fabry mice. Table II shows upregulated or downregulated genes, but normalized after ERT in the kidney of Fabry mice. Liver S100a8, Saal, S100a8, S100a9 and Lcn2 and kidney Npy, Tsp-2 and Tsp-4 expression was significantly upregulated in Fabry mice compared with wild-type mice.

Validation of gene expression using real-time PCR. To verify microarray data, mRNA was detected using semiquantitative RT-PCR and quantitative real-time PCR. Real-time PCR revealed that mRNA expression of liver Saal, S100a8, S100a9 and $L c n 2$ and kidney Npy, Tsp2 and $T s p-4$ was significantly increased in untreated Fabry mice compared with wild-type mice (Figs. 1 and 2). Expression of these genes was normalized by ERT.

Validation of gene expression with Western blotting. Western blot analysis revealed that hepatic expression of Saa1, S100a9

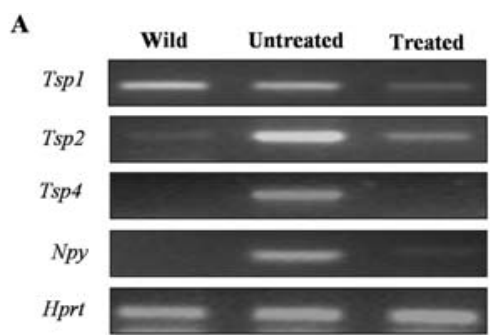

B

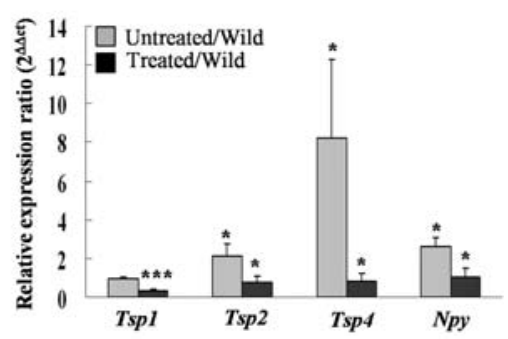

Figure 2. A, Semiquantitative RT-PCR analysis of $T s p 1, T s p 2, T s p 4$, and Npy expression in the mouse kidney. Total RNA from kidneys of untreated, treated and wild-type mice was purified from three mice per group. B, Expression levels of genes in mouse kidney analyzed by quantitative realtime PCR and expressed relative to those of wild-type mice. Data are presented as the means \pm SD of three experiments. ${ }^{*} \mathrm{p}<0.05,{ }^{* *} \mathrm{p}<0.01$, and ${ }^{* * *} \mathrm{p}<0.001$ for wild-type vs untreated Fabry mice or for untreated Fabry vs treated Fabry mice according to Student's t test.
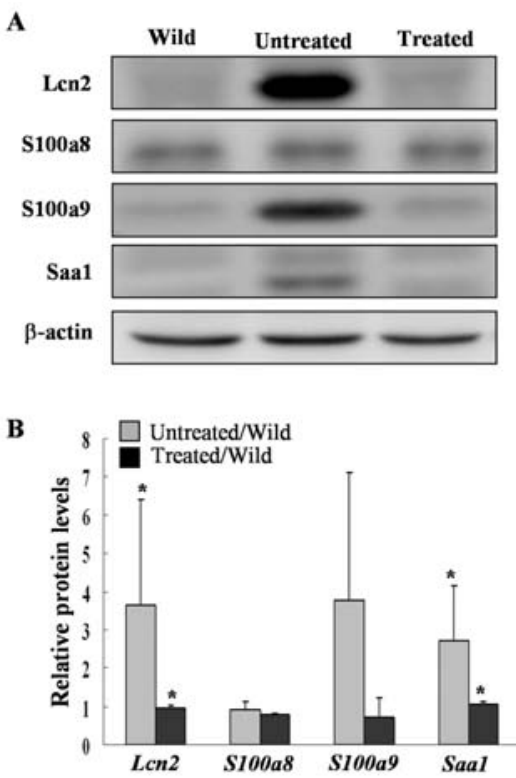

Figure 3. Western blot analysis of the livers of Fabry mice. A, Results of Western blot analysis. B, Protein expression for each group $(n=3)$. Data are expressed as the mean \pm SD. ${ }^{*} \mathrm{p}<0.05$ for wild-type vs untreated Fabry mice or untreated Fabry mice vs ERT Fabry mice.

and Lcn 2 protein was greater in Fabry mice than in wild-type mice. Protein expression in Fabry mice was normalized by ERT (Fig. 3). These findings are consistent with the results of the microarray and real-time PCR experiments. Expression of $\mathrm{S} 100 \mathrm{a} 8$ protein was not elevated in untreated Fabry mice. Expression of kidney Tsp-1, 2 and 4 was not statistically significant in Fabry mice compared to wild-type mice but was reduced in ERT-received Fabry mice (Fig. 4). 
$\mathbf{A}$

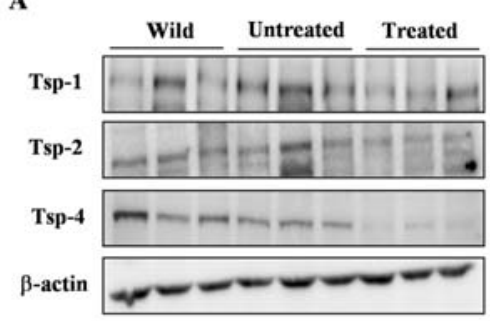

B

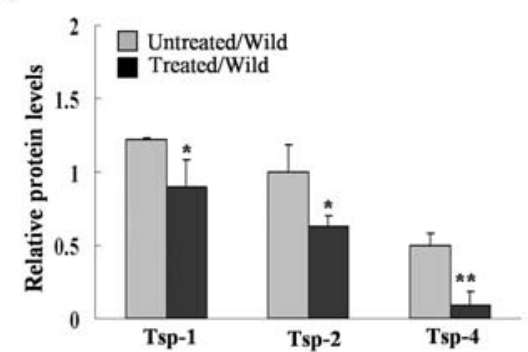

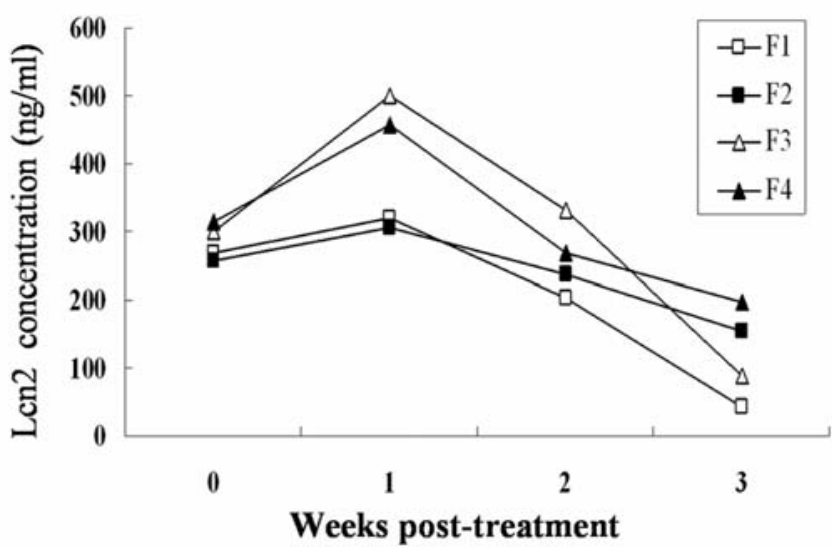

Figure 6. Lcn 2 concentration changes in the plasma of Fabry mice before and after enzyme replacement therapy. The enzyme was administered once a week for three consecutive weeks. Blood sampling was done each week. F1-F4 indicate individual Fabry mice.

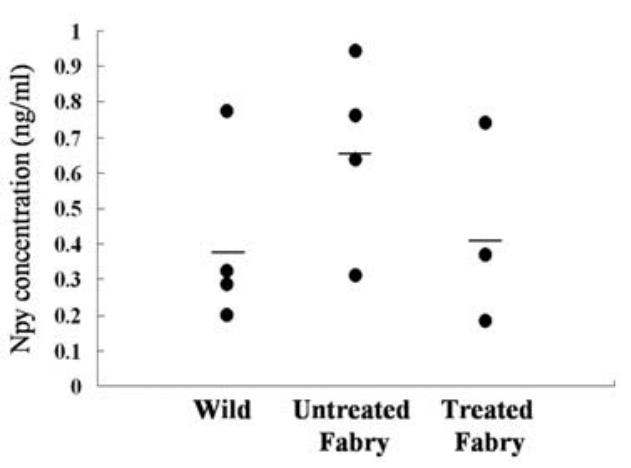

Figure 7. Plasma concentrations of Neuropeptide Y in Fabry mice before and after enzyme replacement therapy. Plasma concentrations of Npy were estimated using an ELISA after extraction of peptides from plasma. The dots indicate individual mice ( $\mathrm{n}=4$ for each group), the bars indicate the mean Npy concentrations for the groups.

Tsp-1 and Lcn2 expression in the kidneys of Fabry mice. To determine whether expression of Lcn2 is associated with that of Tsp-1, Tsp-1 and Lcn2 expression in the kidneys of Fabry mice were analyzed using Western blotting (Fig. 8). Tsp-1 expression was elevated in two out of four Fabry mice. However, Lcn 2 expression was also upregulated in the kidneys of the Fabry mice in which Tsp-1 expression was upregulated. Tsp-1 expression was increased about twofold and Lcn2 expression was increased about sixfold in the kidneys of Fabry mice compared with wild-type mice.

ERT. In order to determine whether Len2 and Npy are usefu biomarkers for diagnosing Fabry disease and monitoring the efficacy of therapy, we studied plasma Lcn2 and Npy concentration changes in Fabry mice. Average plasma Lcn2 and Npy concentrations in untreated Fabry mice were $285.20 \pm 26.87$ and $0.66 \pm 0.27 \mathrm{ng} / \mathrm{ml}$, respectively. Plasma Lcn2 concentrations in Fabry mice were not consistent (Fig. 5). Plasma Lcn 2 concentrations in Fabry mice ranged from 30 to 700 ng/ml. Among Fabry mice with high plasma Lcn2 levels, plasma Lcn 2 concentrations gradually decreased to the values of wild-type mice three weeks after three consecutive weekly ERTs (Fig. 6). Plasma Npy concentrations in Fabry mice were also heterogeneous and were reduced by ERT (Fig. 7).

\section{Discussion}

The most efficient and reliable method of diagnosing Fabry disease is to determine the activity of $\alpha$-galactosidase $\mathrm{A}$ in plasma, isolated leukocytes, or cultured cells. Excessive Gb3 contributes to endothelial dysfunction in Fabry disease (13). As elevated levels of Gb3 and the clinical manifestation of Fabry disease are not necessarily correlated, there is a need to better understand the etiology of this disease and to identify biomarkers for diagnosis, monitoring disease progression and testing the effect of therapies in clinical trials. Moore et al 
$\mathbf{A}$

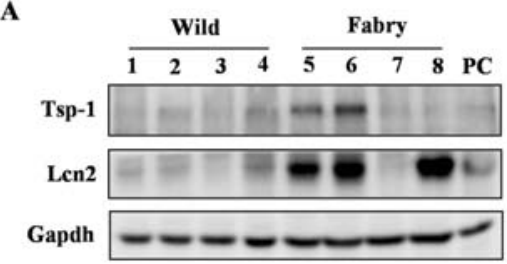

B

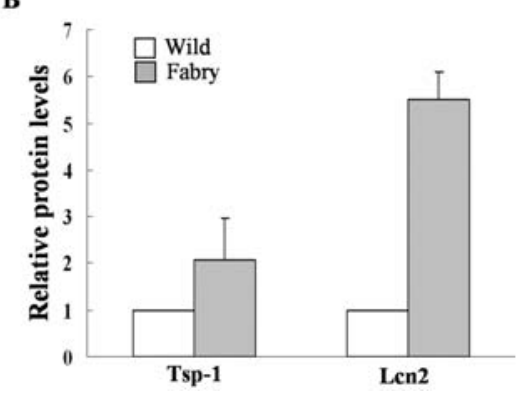

Figure 8. Western blot analysis of the kidneys of Fabry mice. A, Results of Western blot analysis. B, Relative protein expression levels for each group $(n=4)$. Data are expressed as the mean $\pm S D$.

reported a well-designed and systemic microarray study in which a Fabry disease mouse model was used (14). They reported that several important genes are involved in the pathogenesis of Fabry disease, including Rpgrp1, securin and Sod3, and demonstrated multiple and complex cellular abnormalities in this disease (14).

Therefore, we determined whether secreted proteins are useful as biological candidate markers and whether renal gene expression patterns are related to endothelial dysfunction in Fabry disease. The upregulated genes, Saa1, S100a8, S100a9 and Lcn2 in the liver and Npy, Tsp-2 and Tsp-4 in the kidney, were normalized by ERT. Among these genes, Lcn2, Npy, $T s p-2$ and $T s p-4$ were related to angiogenesis as agonists or antagonists.

Serum Amyloid A (SAA) is a superfamily of acute-phase proteins. The level of SAA in the blood increases in response to tissue injury and inflammation. SAA, an important clinical marker for inflammation (15) and precursor protein of secondary reactive amyloidosis (16), contributes to cellular cholesterol homeostasis, modulates intracellular calcium levels and promotes signaling cascades (17-19). In addition, several functions of SAA that were described in the context of inflammation are also compatible with tumor cell invasion and metastasis.

The S100 proteins are a large family of cytoplasmic and extracellular $\mathrm{Ca}^{2+}$-binding proteins characterized by a high degree of amino acid sequence conservation (20). Alterations in S100 function was implicated in many diseases such as Down syndrome, Alzheimer's disease, cardiomyopathy, psoriasis, cystic fibrosis, amyotrophic lateral sclerosis and epilepsy $(21,22)$.

LCN2, also known as 24p3 and neutrophil gelatinaseassociated lipocalin (NGAL), is a secretory glycoprotein that was originally identified in mouse kidney cells and human neutrophil granules $(23,24)$. Several inflammatory stimuli, such as lipopolysaccharides and IL-1, induce LCN2 expression and secretion in these cells $(25,26)$, indicating that LCN2 is involved in the inflammatory responses. However, it was suggested that
LCN2 is a sensitive biomarker of early-stage renal injury $(27,28)$. LCN2 is also important for normal kidney formation in the early stages of mammalian development. Furthermore, LCN2 antagonizes ras-induced angiogenesis through downregulation of VEGF expression and upregulation of Tsp-1 expression (29). Thus, LCN2 is related to endothelial damage in the renal dysfunction observed in Fabry disease. The LCN2 expression levels in Fabry mice were heterogeneous, although plasma LCN2 levels were increased in 9 of 11 Fabry mice (Fig. 5). Endothelial function decreases with age in Fabry mice (30). However, there was no relationship between age and plasma LCN2 level in Fabry mice (data not shown).

Tsp-1 and -2 are matricellular proteins that inhibit angiogenesis in vitro and in vivo (31-33). In addition, several studies show that Tsp-1, fragments of Tsp-1 and peptides derived from Tsp-1 inhibit angiogenesis and cause apoptosis in endothelial cells (34-36). Moreover, Tsp-1 was identified as a novel mediator of cell ischemic injury in the kidney (37). Our microarray data show that Tsp-2 was upregulated in the kidneys of Fabry mice compared with wild-type mice. In accordance with heterogeneity of Lcn2 expression in Fabry mice, expression of Tsp-1, -2 and -4 was not consistent (Fig. 4). The Lcn2 expression level is proportionally related to the expression of Tsp-1 (Fig. 8). Our study revealed for the first time that Lcn2, Tsp-1 and -2 expression are upregulated in the kidney of the Fabry mouse, which suggests that increased Tsp-1 and -2 expression cause endothelial cell damage.

NPY, a 36 amino acid peptide of the pancreatic polypeptide family, is one of the most abundantly expressed peptides in the nervous system (38). Because it has six different receptors (Y1 to Y6) that are expressed in many tissues, this neuropeptide $\mathrm{Y}$ is involved in the regulation of many biological functions (38-40). The presence of NPY in the dense plexus of nerve fibers around the renal juxtaglomeular apparatus was reported (40). Several investigators reported that the circulating concentration of NPY is significantly increased in chronic renal failure patients (40-42). In addition, we found that kidney Npy mRNA levels and plasma Npy concentrations were greater in Fabry mice than in wild-type mice. However, the difference in the plasma concentration of Npy between untreated Fabry mice and wild-type mice was not statistically significant. Further studies are needed to investigate factors affecting Npy concentration in Fabry mice, such as renal function.

In conclusion, we demonstrated that liver Saal, S100a8, S100a9 and Lcn2 and kidney Npy were significantly upregulated in Fabry mice compared with wild-type mice. Saa1, S100a8, S100a9 and Lcn2 modulate inflammation and Lcn2, Npy and Tsp may be associated with vascular and renal functions. Plasma Lcn2 and Npy levels were detected and are related to Fabry disease progression. These genes may play important roles in the pathogenesis of Fabry disease and Lcn2 and Npy present promising targets for the development of biomarkers in patients with Fabry disease.

\section{Acknowledgements}

This study was supported by a grant from the Korea 21 R\&D project (A010384) of the Ministry of Health and Welfare, Republic of Korea. 


\section{References}

1. Brady RO: Enzymatic abnormalities in diseases of sphingolipid metabolism. Clin Chem 13: 565-577, 1967.

2. Brady RO and Schiffmann R: Clinical features of and recent advances in therapy for Fabry disease. JAMA 284: 2771-2775, 2000.

3. Ries M, Gupta S, Moore DF, Sachdev V, Quirk JM, Murray GJ Rosing DR, Robinson C, Schaefer E, Gal A, Dambrosia JM, Garman SC, Brady RO and Schiffmann R: Pediatric Fabry disease. Pediatrics 115: E344-E355, 2005.

4. Eng CM, Banikazemi M, Gordon RE, Goldman M, Phelps R, Kim L, Gass A, Winston J, Dikman S, Fallon JT, Brodie S, Stacy CB, Mehta D, Parsons R, Norton K, O'Callaghan M and Desnick RJ: A phase $1 / 2$ clinical trial of enzyme replacement in fabry disease: pharmacokinetic, substrate clearance, and safety studies. Am J Hum Genet 68: 711-722, 2001.

5. Schiffmann R, Murray GJ, Treco D, Daniel P, Sellos-Moura M, Myers M, Quirk JM, Zirzow GC, Borowski M, Loveday K, Anderson T, Gillespie F, Oliver KL, Jeffries NO, Doo E, Liang TJ, Kreps C, Gunter K, Frei K, Crutchfield K, Selden RF and Brady RO: Infusion of alpha-galactosidase $\mathrm{A}$ reduces tissue globotriaosylceramide storage in patients with Fabry disease. Proc Natl Acad Sci USA 97: 365-370, 2000.

6. Schiffmann R, Ries M, Timmons M, Flaherty JT and Brady RO: Long-term therapy with agalsidase alfa for Fabry disease: safety and effects on renal function in a home infusion setting. Nephrol Dial Transplant 21: 345-354, 2006.

7. Vedder AC, Linthorst GE, Houge G, Groener JE, Ormel EE, Bouma BJ, Aerts JM, Hirth A and Hollak CE: Treatment of Fabry disease: outcome of a comparative trial with agalsidase alfa or beta at a dose of $0.2 \mathrm{mg} / \mathrm{kg}$. PLoS ONE 2: e598, 2007.

8. Ohshima T, Murray GJ, Swaim WD, Longenecker G, Quirk JM, Cardarelli CO, Sugimoto Y, Pastan I, Gottesman MM, Brady RO and Kulkarni AB: alpha-Galactosidase A deficient mice: a model of Fabry disease. Proc Natl Acad Sci USA 94: 2540-2544, 1997.

9. Kusiak JW, Quirk JM and Brady RO: Purification and properties of the two major isozymes of alpha-galactosidase from human placenta. J Biol Chem 253: 184-190, 1978.

10. Ullman MD and McCluer RH: Quantitative analysis of plasma neutral glycosphingolipids by high performance liquid chromatography of their perbenzoyl derivatives. J Lipid Res 18: 371-378, 1977.

11. De Kok JB, Roelofs RW, Giesendorf BA, Pennings JL, Waas ET, Feuth T, Swinkels DW and Span PN: Normalization of gene expression measurements in tumor tissues: comparison of 13 endogenous control genes. Lab Invest 85: 154-159, 2005.

12. Livak KJ and Schmittgen TD: Analysis of relative gene expression data using real-time quantitative PCR and the 2(-Delta Delta C(T)) method. Methods 25: 402-408, 2001.

13. Moore DF, Gelderman MP, Fuhrmann SR, Schiffmann R, Brady RO and Goldin E: Fabry disease and vascular risk factors: future strategies for patient-based studies and the knockout murine model. Acta Paediatr (Suppl) 95: 69-71, 2006.

14. Moore DF, Gelderman MP, Ferreira PA, Fuhrmann SR, Yi H, Elkahloun A, Lix LM, Brady RO, Schiffmann R and Goldin E: Genomic abnormalities of the murine model of Fabry disease after disease-related perturbation, a systems biology approach. Proc Natl Acad Sci USA 104: 8065-8070, 2007.

15. Malle E and De Beer FC: Human serum amyloid A (SAA) protein: a prominent acute-phase reactant for clinical practice. Eur J Clin Invest 26: 427-435, 1996.

16. Husebekk A, Skogen B, Husby G and Marhaug G: Transformation of amyloid precursor SAA to protein AA and incorporation in amyloid fibrils in vivo. Scand J Immunol 21: 283-287, 1985.

17. Badolato R, Johnston JA, Wang JM, McVicar D, Xu LL, Oppenheim JJ and Kelvin DL: Serum amyloid A induces calcium mobilization and chemotaxis of human monocytes by activating a pertussis toxin-sensitive signaling pathway. J Immunol 155 : 4004-4010, 1995.

18. Artl A, Marsche G, Lestavel S, Sattler W and Malle E: Role of serum amyloid A during metabolism of acute-phase HDL by macrophages. Arterioscler Thromb Vasc Biol 20: 763-772, 2000.

19. Baranova IN, Vishnyakova TG, Bocharov AV, Kurlander R, Chen Z, Kimelman ML, Remaley AT, Csako G, Thomas F, Eggerman TL and Patterson AP: Serum amyloid A binding to CLA-1 (CD36 and LIMPII analogous-1) mediates serum amyloid A protein-induced activation of ERK $1 / 2$ and p38 mitogenactivated protein kinases. J Biol Chem 280: 8031-8040, 2005.
20. Rustandi RR, Baldisseri DM, Drohat AC and Weber DJ: Structural changes in the C-terminus of $\mathrm{Ca}^{2+}$-bound rat S100B (beta beta) upon binding to a peptide derived from the C-terminal regulatory domain of p53. Protein Sci 8: 1743-1751, 1999.

21. Heizmann CW: The multifunctional S100 protein family. Methods Mol Biol 172: 69-80, 2002.

22. Heizmann CW, Fritz G and Schafer BW: S100 proteins: structure, functions and pathology. Front Biosci 7: D1356-D1368, 2002

23. Hraba-Renevey S, Turler H, Kress M, Salomon C and Weil R: SV40-induced expression of mouse gene $24 \mathrm{p} 3$ involves a posttranscriptional mechanism. Oncogene 4: 601-608, 1989.

24. Kjeldsen L, Johnsen AH, Sengelov H and Borregaard N: Isolation and primary structure of NGAL, a novel protein associated with human neutrophil gelatinase. J Biol Chem 268: 10425-10432, 1993.

25. Liu Q and Nilsen-Hamilton M: Identification of a new acute phase protein. J Biol Chem 270: 22565-22570, 1995.

26. Jayaraman A, Roberts KA, Yoon J, Yarmush DM, Duan X, Lee K and Yarmush ML: Identification of neutrophil gelatinase-associated lipocalin (NGAL) as a discriminatory marker of the hepatocytesecreted protein response to IL-1beta: a proteomic analysis. Biotechnol Bioeng 91: 502-515, 2005.

27. Mishra J, Mori K, Ma Q, Kelly C, Barasch J and Devarajan P: Neutrophil gelatinase-associated lipocalin: a novel early urinary biomarker for cisplatin nephrotoxicity. Am J Nephrol 24: 307$315,2004$.

28. Mishra J, Dent C, Tarabishi R, Mitsnefes MM, Ma Q, Kelly C, Ruff SM, Zahedi K, Shao M, Bean J, Mori K, Barasch J and Devarajan P: Neutrophil gelatinase-associated lipocalin (NGAL) as a biomarker for acute renal injury after cardiac surgery. Lancet 365: 1231-1238, 2005.

29. Venkatesha S, Hanai J, Seth P, Karumanchi SA and Sukhatme VP: Lipocalin 2 antagonizes the proangiogenic action of ras in transformed cells. Mol Cancer Res 4: 821-829, 2006.

30. Heare T, Alp NJ, Priestman DA, Kulkarni AB, Qasba P, Butters TD, Dwek RA, Clarke K, Channon KM and Platt FM: Severe endothelial dysfunction in the aorta of a mouse model of Fabry disease; partial prevention by N-butyldeoxynojirimycin treatment. J Inherit Metab Dis 30: 79-87, 2007.

31. Kyriakides TR, Leach KJ, Hoffman AS, Ratner BD and Bornstein P: Mice that lack the angiogenesis inhibitor, thrombospondin 2, mount an altered foreign body reaction characterized by increased vascularity. Proc Natl Acad Sci USA 96: 4449-4454, 1999.

32. Tolsma SS, Volpert OV, Good DJ, Frazier WA, Polverini PJ and Bouck N: Peptides derived from two separate domains of the matrix protein thrombospondin-1 have anti-angiogenic activity. J Cell Biol 122: 497-511, 1993.

33. Dawson DW, Pearce SF, Zhong R, Silverstein RL, Frazier WA and Bouck NP: CD36 mediates the in vitro inhibitory effects of thrombospondin-1 on endothelial cells. J Cell Biol 138: 707-717, 1997.

34. Guo N, Krutzsch HC, Inman JK and Roberts DD: Thrombospondin 1 and type I repeat peptides of thrombospondin 1 specifically induce apoptosis of endothelial cells. Cancer Res 57: 1735-1742, 1997.

35. Jimenez B, Volpert OV, Crawford SE, Febbraio M, Silverstein RL and Bouck N: Signals leading to apoptosis-dependent inhibition of neovascularization by thrombospondin-1. Nat Med 6: 41-48, 2000.

36. Nor JE, Mitra RS, Sutorik MM, Mooney DJ, Castle VP and Polverini PJ: Thrombospondin-1 induces endothelial cell apoptosis and inhibits angiogenesis by activating the caspase death pathway. J Vasc Res 37: 209-218, 2000.

37. Thakar CV, Zahedi K, Revelo MP, Wang Z, Burnham CE, Barone S, Bevans S, Lentsch AB, Rabb H and Soleimani M: Identification of thrombospondin 1 (TSP-1) as a novel mediator of cell injury in kidney ischemia. J Clin Invest 115: 3451-3459, 2005.

38. Wettstein JG, Earley B and Junien JL: Central nervous system pharmacology of neuropeptide Y. Pharmacol Ther 65: 397-414, 1995.

39. Jacques D and Abdel-Samad D: Neuropeptide Y (NPY) and NPY receptors in the cardiovascular system: implication in the regulation of intracellular calcium. Can J Physiol Pharmacol 85: 43-53, 2007

40. Magni P: Hormonal control of the neuropeptide Y system. Curr Protein Pept Sci 4: 45-57, 2003.

41. Zoccali C, Mallamaci F, Tripepi G, Benedetto FA, Parlongo S, Cutrupi S, Bonanno G, Rapisarda F, Fatuzzo P, Seminara G, Cataliotti A and Malatino LS: Neuropeptide Y, left ventricular mass and function in patients with end stage renal disease. J Hypertens 21: 1355-1362, 2003.

42. Kokot F, Adamczak M, Wiecek A, Spiechowicz U and Mesjasz J: Plasma immunoreactive leptin and neuropeptide $\mathrm{Y}$ levels in kidney transplant patients. Am J Nephrol 19: 28-33, 1999. 